al-Ihkam: Jurnal Hukum dan Pranata Sosial, 15 (1), 2020: 153-172

ISSN: 1907-591X, E-ISSN: 2442-3084

DOI: http://doi.org/10.19105/al-ihkam.v15i1.2682

\title{
The Implementation of Islamic Value Absorption in Regional Regulations on Districts at Madura
}

\author{
Agung Ali Fahmi \\ Fakultas Hukum Universitas Trunojoyo Madura Jl. Telang Kamal Bangkalan \\ Email:agungalifahmi@trunojoyo.ac.id \\ Muwaffiq Jufri \\ Fakultas Hukum Universitas Trunojoyo Madura Jl. Telang Kamal Bangkalan \\ Ansori \\ Fakultas Hukum Universitas Trunojoyo Madura Jl. Telang Kamal Bangkalan
}

Article history: Received: 25 Oktober 2019, Accepted: 27 Mei 2020, Published: 27 Juni 2020

\begin{abstract}
:
In Madurese society, the existing sharia and/or sharia nuanced Regional Regulations is believed to cause a lot of conflict. This is particularly because Indonesia itself is not a religious state in a formal way. Therefore, it is necessary to know how the legal politics on values absorption or Sharia legal provisions in Madura Regional Regulations is. This study is a normative legal research. It includes a conceptual, statutory, and case approach. The finding shows that the application and/or absorption of Sharia in Madura are due to attached religious values in societies' daily life. The research found that the application and/or absorption of the Islamic values in Madura regional legal products have two types. First is direct absorption and/or application of regional legal products in the form of Perda or Perbup. Second is indirect yet substantial absorption and/or application of Islamic legal values to regional legal products.
\end{abstract}

Author correspondence email: agungalifahmi@trunojoyo.ac.id Available online at: http:// ejournal.iainmadura.ac.id/index.php/alihkam/ Copyright (c) 2020 by al-ihkam. All Right Reserved 


\title{
Keywords:
}

Islamic Value; Regional Regulation; Madura

\begin{abstract}
Abstrak:
Di Madura lahir beberapa Peraturan Daerah Syari'ah dan/atau bernuansa syari'ah. Padahal Indonesia bukan negara agama. Karena itu, munculnya Peraturan Daerah seperti itu yang diyakini akan banyak menimbulkan konflik dalam masyarakat, maka perlu untuk diketahui bagaimana politik hukum penyerapan nilai atau ketentuan hukum syariah dalam Peraturan Daerah Kabupaten se-Madura. Jenis penelitian yang digunakan dalam kajian ini ialah metode penelitian hukum normatif, dengan pendekatan konsep (conseptual approach), pendekatan perundangundangan (statute approach), dan pendekatan kasus (case approach). Temuannya adalah penerapan dan/atau penyerapan hukum syariah di wilayah pemerintahan daerah se-Madura, terjadi dikarenakan masyarakat Madura dalam kehidupan sehari-hari memegang teguh ajaran agama. Maka setelah dilakukan penelitian bahwa Penerapan dan/atau penyerapan nilai hukum Islam dalam produk hukum daerah di Madura terbagi atas dua jenis; Pertama; penyerapan dan/atau penerapan secara langsung pada produk hukum daerah, baik berupa Perda ataupun Perbup. Kedua, penyerapan dan/atau penerapan nilai hukum Islam pada produk hukum daerah tidak secara langsung berwujud produk hukum syariah, tetapi secara substansial, materi yang dimuat dalam produk hukum tersebut telah menyerap nilai-nilai hukum Islam di dalamnya.
\end{abstract}

Kata Kunci:

Nilai-nilai Islam; Peraturan Daerah; Madura

\section{Introduction}

The establishment and implementation of sharia law in Madura are mainly because Madurese people have long been upholding Islamic values in their daily life in addition to their strong social 
relationship. ${ }^{1}$ This is also supported by the spirit to establish Madura Province which also grows from strong religious awareness of Madurese people in all levels. ${ }^{2}$ For instance, in last 2011, around 1,032 mosques and 5,187 musholla (prayer room) in Pamekasan were built on waqf land from people. They become not only places to worship God, but also for educational and economic activities as well. This reality shows that Madurese have the strong religiousity. ${ }^{3}$

Nowadays, the development of Islamic law absorption in districts of Madura is clear, among others, from the following facts; First, in Pamekasan district, a No. of Islamic nuance Regional Regulations (Perda) have been applied. Those regulations include the Regulations on the Islamic Community Development Movement (Gerbang Salam), the Prohibition of alcohols as well as prostitution, regulation to cover up 'aurat in formal schools and obligation for students to have ability in reading the Quran. According to the old Regent, Syafi'i, these local regulations are Pamekasan people's aspirations in which the central government officially approved aftwerd. They aim at developing mental and moral of Pamekasan's people without any discrimination. ${ }^{4}$

Second, in Bangkalan district, since November 2018, the regional government has been drafting Regional Regulations to establish Bangkalan as a city of Dzikir and Sholawat. ${ }^{5}$ This is a concrete step

\footnotetext{
1 Yanwar Pribadi, "Religious Networks in Madura (Pesantren, Nahdlatul Ulama and Kiai as the Core of Santri Culture)", Al-Jami'ah, Volume. 51, No. 1, (2013 M/1434 $\mathrm{H}), 2$

${ }^{2}$ Agung Ali Fahmi. "Peluang Hukum Propinsi Madura", Jawapos, 06 Oktober 2016 : https://www.jawapos.com/opini/06/10/2016/peluang-hukum-provinsi-madura. (accessed on 21 March 2019).

3 Agung Ali Fahmi, Misbahul Munir and Yahya Suryawinata. Optimalisasi Fungsi Masjid Melalui Sertifikasi Wakaf Tanah dan Penguatan Organisasi Takmir sebagai Peningkatan Empati Sosial serta Ekonomi Masyarakat dalam Menangkal Radikalisme Agama di Pamekasan. (Proceeding on Seminar Nasional Budaya Madura I, Madura Dalam Kacamata Sosial, Budaya, Ekonomi, Agama, Kebahasaan dan Pertanian. Puslit Budaya dan Potensi Madura, LPPM UTM 2014).

4 Mas, "Bupati-DPRD Kompak Pertahankan Perda Syariah”, Globalnews, 24 Juli 2016 : http://global-news.co.id/2016/06/bupati-dprd-kompak-pertahankan-perdasyariah/. (Accessed on 21 March, 2019).

${ }^{5}$ Eko/mas, "Susun Perda Dzikir dan Sjolawat, Ra Latif : Yang Penting Kita Bisa Mengaplikasikannya", www.bangkalankab.go.id, 28 November, 2018 : http:/ / www.bangkalankab.go.id/v5/dat_berita.php?nart=1349/Susun_Perda_Kota
} 
starting from an idea to maintain religious thoughts in Bangkalan City in order to make it integrated in daily life of their people. This cannot be separated from pesantren culture such as sarong and kopyah, Qur'an recitation in mushalla, etc. Before, through Bangkalan Regent Decree No. 188.45 / 148 / 433.013 / 2015 on August 28, 2015 which was issued in an event attended by government and Islamic scholars, Bangkalan officially declared itself as a city of dzikir and shalawat. This certainly strengthened the impression of religious community in the city.

Third, in 2018, the Faculty of Islamic sciences at the University of Trunojoyo Madura along with the Suramadu Regional Management Board, compiled and recommended the design of the development of Madura Islamic tourism. It recommended the government to draft an Islamic Tourism Regulation.

Another example to illustrate religiousity of Madurese people is one of factors beyond the failure of the Suramadu Bridge Development Management Board (BPWS) program on Madura's industrialization. It was believed that the different perceptions about the meaning and scope of this program really mattered. The jargon of industrialization was generally rejected because the Islamic scholars worried that its negative consequences would cause moral deterioriation, the growth of prostitution, gambling and other disobedience which potentially damage Madurese's religiousity. ${ }^{6}$ However, this challenge is increasingly severe considering that since Suramadu was made free on October 27, 2018,7 it has been opening up

Dzikir_dan_Sholawat,_Ra_Latif:_Yang_Penting_Kita_Bisa_Mengaplikasikannya. (Accessed on 21 March 2019). See also, Ahmad Faisol, "Ulama Desak Legislatif Sahkan Bangkalan Dzikir dan Sholawat", surabaya.tribunnews.com, 24 August 2015 : http:/ / surabaya.tribunnews.com/2015/08/24/ulama-desak-legislatif-sahkan-perdabangkalan-dzikir-dan-shalawat. (Accessed on 21 March 2019).

6 Agung Ali Fahmi, Uswatun Hassanah and Yahya Suryawinata. "Resolusi Penolakan Daerah Terhadap Badan Pengelolaan Suramadu Pasca Jembatan Surabaya-Madura dalam Perspektif NKRI. 2015. Seminar Nasional Industrialisasi Madura. Fakultas Teknik Universitas Trunojoyo Madura.

7 Ghinan Salman, "Resmi Dgiratiskan, Jembatan Suramadu Jadi Non Tol", regional.kompas.com, $\quad 28 \quad$ October, 2018

https://regional.kompas.com/read/2018/10/28/07453791/resmi-digratiskanjembatan-suramadu-jadi-jalan-non-tol. (Accessed on 21 March, 2019). 
extraordinary economic growth opportunities for Madurese people or vice-versa. ${ }^{8}$

The mentioned dynamics of legal formation seem to be in line with the development of regional autonomy which enables local governments to regulate all local matters into Regional Regulations (Perda). This especially applies on regional regulations regarding regional taxes and retribution. On the other hand, some local people want to implement sharia-based laws in their regions and this inevitable leads to a controversy. ${ }^{9}$ Those who agree with this opinion think that the Sharia Regional Regulation is expected to be a solution for accelerating regional development without losing the local identity and religiosity. Meanwhile, those who disagree think that it will only trigger national disunity due to discrimination to the minorities.

The implementation of various provisions and absorption on Islamic law values in governmental sector is an indicator on religious right in Indonesia. It assures individual's rights to determine, believe, and practice religion as a core part of human rights that nothing or no one can reduce it for any reason. Therefore, the existence of this right obliges government to respect, protect, and fulfill citizens' right as a manifestation of state's recognition on the human rights principles and values as also ratified in international agreements. ${ }^{10}$ However, it still becomes important on how a statutory regulation should not create discrimination and anxiety of minority groups. ${ }^{11}$ This is mainly because the essential purpose of sharia implementation is to maintain

\footnotetext{
8 Agung Ali Fahmi, "Suramadu Gratis, Awal Kebangkrutan Ekonomi Madura?". www.jawapos.com, 28 October, 2018 : https://www.jawapos.com/jpgtoday/28/10/2018/suramadu-gratis-awal-kebangkrutan-ekonomi-madura. (Accessed on 21 March 2019).

9 Mohammad Alim, "Perda Bernuansa Syariah dan Hubungannya dengan Konstitusi", JURNAL HUKUM, VOL. 17, NO. 1 (Januari, 2010),. 120

10 Ansori, et al. Penyelesaian Konflik Aliran Keagamaan Berbasis Nilai Kearifan Lokal (Studi Kasus di Wilayah Madura), Fakultas Hukum Universitas Brawijaya and based on Surat Perjanjian Nomor: 05/PKK-FHUB/PEN/2016.

11 Agung Ali Fahmi. Implementasi Jaminan Hukum HAM atas Kebebasan Beragama Di Indonesia. 2011. Jogjakarta: Interpena,. 23.
} 
and protect the dignity of humanity which is oftenly referred as maqâshid al-syarî'ah in Islamic studies. ${ }^{12}$

Therefore, the religious freedom in Indonesia is so important that it needs to ensure that everyone can carry out religious services and values without having to establish any Islamic or theocratic state. ${ }^{13}$ Moreover, this guarantee is affirmed in the 1945 Constitution, Article 28 E (1); Article 28 I (1); Article 29 (2); and Article 31 (5). It also got along in Article 18 of Law No. 12 of 2005 concerning the Ratification of the International Covenant on Civil and Political Rights (International Covenant on Civil and Political Rights). ${ }^{14}$ In addition to it, regional enthusiasm for developing its areas based on local potential, including people values, was perfectly facilitated by Law No. 23 of 2014 concerning Regional Government. ${ }^{15}$

Furthermore, religious freedom was not mainly born from universal human rights concept. It is mainly on Indonesian cultural traditions namely a spirit of harmony, peace and respect for differences. This is clear from the fact that in the ancient times, there found no conflict among religions in the entire archipelago. History even records that in the golden age of Majapahit, the government gave freedom to its citizens to believe in any religion and carry out religious activities without pressure from anyone. ${ }^{16}$ As a consequence, both absorption and implementation on Islamic law values need to always in line with Pancasila, the 1945 Constitution, and NKRI (Unitary State of the Republic of Indonesia) values.

\footnotetext{
12 Muwaffiq Jufri, “Nuansa Maqhasidu al-Syari'ah dalam Undang-undang No. 39 tahun 1999 tentang Hak Asasi Manusia", : e-journal.metrouniv.ac.id : http://ejournal.metrouniv.ac.id/index.php/istinbath/article/view/735 (Accessed on 21 March 2019).

13 Implementasi Kebebasan Beragama Menurut UUD Republik Indonesia Tahun 1945. Thesis. 2010. Jakarta: Program Magister Hukum Kenegaraan. Fakultas Hukum. Universitas Indonesia.

14 Undang-Undang Nomor 12 tahun 2005 tentang Pengesahan International Covenant On Civil And Political Rights (Kovenan Internasional Tentang Hak-Hak Sipil Dan Politik) Lembaran Negara Republik Indonesia Tahun 2005 Nomor 119.

15 Undang-Undang Nomor 23 Tahun 2014 tentang Pemerintah Daerah. Lembaran Negara Republik Indonesia Tahun 2014 Nomor 244.

16 Muwaffiq Jufri, "Perbandingan Pengaturan Hak Kebebasan Beragama antara Indonesia dengan Majapahit", Jurnal Konstitusi, Volume 14 No. 2 (Juni 2017),. 398.
} 
This research then becomes important due to its novelty as it is still rare to find researches in analyzing the absorption of Islamic value and implementation of sharia regulation in Madura. Moreover, this research focuses on the politic of law beyond the regulation. As mentioned by Padmo Wahyono, politic of law is the basic law policy of government which have been and are still valid extracted from living values in society and aiming to achieve visions of a state. ${ }^{17}$

\section{Research Method}

This study used a normative legal research method with conceptual, statutory and case approaches. The main legal materials were the 1945 Constitution of the Republic of Indonesia; UU No. 12 of 2011 concerning Formation of Regulations and Rules; UU No. 39 of 1999 concerning Human Rights; UU No. 12 of 2005 concerning Ratification of the ICCPR; and the PNPS Act of 1965.

In addition to those, secondary and tertiary legal materials consisted of analytical materials such as scientific books, journal articles, proceedings, website contents, and legal dictionaries. All those sources of law were then analyzed using prescriptive-analytic analysis techniques to find answers related to the development of the implementation and/or absorption of Islamic legal values to regional legal products in Madura.

\section{Legal Politics of Islamic Law Absorption in Madura Legal Products}

Discussion on the implementation Islamic law (sharia) to legal products at both national and regional legal products continues to be an interesting theme for debate. Until now, this theme remains to emerge in the midst of incessant issues related to formalization of values and/or the content of Islamic law in national positive law. ${ }^{18}$ In fact, the spreading issues are no longer at the level of legislation but have been regarded to the state form such as the issue of Islamic State of Indonesia (NII) and khilafah concept by Hizbut-Tahrir.

\footnotetext{
17 Padmo Wahyono. Indonesia, Negara Berdasarkan atas Hukum Cet. II,. 1986. Jakarta: Ghalia Indonesia,. 160.

18 Eri Hariyanto, "Gerbang Salam; Telaah atas Pelaksanaannya di Kabupaten Pamekasan", Jurnal Karsa, Vol. 15 No. 1. (August 2009),. 73-74.
} 
Madura is an island whose population is predominantly Moslem. It becomes academically interesting, therefore, to analyze the form of Madura local legal products regarding to the implementation and/or absorption of Islamic values as well as legal values. The study limits its scope to identify the clustering on those syar'i legal products" on whether they only cover materials on "ubûdiyah and social community or also on muâmalah in the context of the Indonesian law.

According to the law political perspective, the regulation that the authority had ratified must be based on local people's values. Maduresse people, in this context, have strong social-religious background in implementing Islam. Therefore, implementation of Islamic values based doctrine becomes inevitable to ensure its enactment among local people after the issuance of any law legality. .

\section{Sharia-Nuanced Regional Legal Products in Pamekasan}

This district has long time applied some regional legal products reflecting Islamic beliefs as well as Islamic law values. In the past few years, this area had even affirmed its identity as an area of "Gerbang Salam"19 that seeks to mobilize and build Islamic nuances in society both within the scope of government and in terms of society interaction. ${ }^{20}$ Among others, those legal products are; Regional Regulation No. 18 of 2001 concerning Prohibition of Alcoholic Beverages. This Perda is a follow-up action after the establishment of the Institute of Islamic Sharia Study and Application (LP2SI) as an effort to implement the Islamic sharia in Pamekasan. LP2SI itself was established by local government while its member consisted of a No. of 'ulama, leaders of Pamekasan Islamic boarding schools (pesantren) as well as religious figures affiliated to several Islamic organizations such as NU, Muhammadiyah, Al-Irsyad, Persatuan Islam (Persis) and Sarekat Islam (SI). ${ }^{21}$

\footnotetext{
19 Maimun \& Ainul Haq, "Melacak Motivasi dan Efektivitas Peraturan Daerah Bernuansa Syariah di Pamekasan", Al-Ihkam, Volume 13, Nomor 2, (Juni 2018), 128.

20 Ibid, 148.

21 Abd A'la, et al, "Islamism in Madura: From Religious Symbolism to Authoritarianism", Journal Of Indonesian Islam, Volume 12, Number 02, (December 2018), 168.
} 
Regional Regulation No. 18 of 2004 concerning the Prohibition on Prostitution. This Regional Regulation aims to strengthen the commitment to define Pamekasan as a Gerbang Salam city. Furthoremore, it is also an official attitude of regional government in eradicating all practices of prostitution. The idea of this Perda came from consideration to convince people on very big disadvantages of prostitution that will impact on the quality of people's lives. Article 5 (2) on violations of this Perda even threatens the subject with imprisonment for a maximum of 6 (six) months.

Regional Regulation No. 7 of 2008 concerning Management of zakat, Infaq and shadaqah. This regulation aims to provide facilities for local people in fulfilling their religious obligations in terms of zakat, infaq and shadaqah. In the other words, the this rule was intended to increase obligation fulfillment on zakat, infaq, and shadaqah in Pamekasan. It also focuses on the management of sustainable zakat funds by turning it into capital as an effort to create a prosperous society.

Regional Regulation No. 5 of 2010 concerning Grants for Hajj Operational Costs. This aims to provide legal legitimacy to manage pilgrimage funds for outstanding employees and community leaders who are proven to have made many contributions to Moslem community development as the Gerbang Salam mission. Regional Regulation No. 4 of 2014 concerning Al-Qur'an Reading Skills for Muslim Students. This regulation was issued to motivate children at their early ages to read the Qur'an properly and correctly. It then requires each level of educational institutions to provide an extracurricular program to train their students for good and correct Qur'anic recitation while setting the long term goal to create knowledgeable learners who devote to God Almighty.

Regional Regulation No. 5 of 2014 concerning Control on Activities during Ramadhan Month. The existence of this regulation aims to glorify the greatness of Ramadhan as the most precious month for Moslems. This controlling step also heads for creating peaceful and comfortable atmosphere for fasting people. The interesting thing about this Perda is its coverage not only on regulation of restaurants and entertainment places, but also provisions that the Qur'anic recitation forum (tadarus) on the mosque loudspeaker must not exceed midnight.

Regional Regulation No. 14 of 2014 concerning Management of Hotels, Lodging and Boarding Houses. The issuance of this Perda aims to provide guidance to the lodging business owners in order to support local tourism development programs without breaking any 
socially and religiously established rules. The objectives of this Perda; Creating Pamekasan as a religious area, strengthening the image of Pamekasan as the city of education, culture, services and commerce with a global orientation while upholding cultural values, morality and local wisdom, protecting interest of the whole parties and creating security, peace and order as well, Encouraging development of local tourism industry.

Regional Regulation No. 1 of 2017 concerning Implementation of Social Order. The issuance of this regulation is to assure social order in people's daily life activities relating to the existence and attitude of certain groups such as beggars, street children, buskers, homeless people, and immoral people. Regional Regulation No. 3 of 2017 concerning Implementation of Madrasah Diniyah which serves as an implementation of the Gerbang Salam program as an effort to create Pamekasan religious community. Specifically, it provides religious knowledge for students who only attend public education institutions. It is expected that this type of students can get balanced knowledge and qualified in religious understanding.

Regional Regulation No. 3 of 2015 concerning Practice of Entertainment and Recreation Bussiness. It is as follow up step responding the mushrroming and fast development of entertainment industry which potentially leads to immoral practices and violates local propriety traditions. Article 6 (3a) mentioned that every entertainment spot and tourism destination must uphold living religious and propriety values as well as tradition by providing some following facilities; Proper facilities for ritual ablution and cleansing, available facilities to worship easily, halal food and drinks, safe, comfortable and conducive atmosphere and facilities for both family and business purposes, art, cultural performances and attractions suitable with living religious norms, customs and culture, and moral values, assurence on healthy and clean sanitation as well as environment.

Regent Regulation No. 14 of 2016 concerning Karaoke Entertainment Business. This regulation is a follow-up step following the issuance of Regional Regulation of Pemekasan No. 3 of 2015 concerning the Practice of Entertainment and Recreation Bussiness. It aims to provide legal certainty on the existence of karaoke business so that it can comply with both living social norms and religious values. 
The regulation requires several important things in Pamekasan karaoke business provider including; No criminal or immoral activities ranging from gambling, immoral acts, drug trafficking and use, alcoholic beverages consumption, to others thing violating living legal rules and tradition, bright and permanent lighting, airtight karaoke room with visible glass doors, lady companions with polite dress and proper appearance, commitment to close the service during religious holidays, especially in Ramadhan, full responsible on available lady companions.

Regent Regulation No. 300 of 2009 concerning the Establishment of Gerbang Salam as preaching model and strategy. This aims to make Gerbang Salam program as sustainable movement in order to build religious society while maintaining local characters. This regulation further explains vision, mission, goal, objectives, and implementation of Gerbang Salam programs. This also contains official definition and main interpretation on the Gerbang Salam in a legal product. Some of the main programs in the movement include; Building an Islamic family, building and developing an Islamic education system, building and developing social systems of Islamic civilized society, making design and implementating the development program on Islamic governmental officers, building an Islamic based social and economic life social and islamic-based economy while avoiding any form of economic systems contrary to Islamic values.

\section{Sharia-Nuanced Regional Legal Products in Sampang}

Even though Sampang does not openly declare itself as a "sharia district" as Pamekasan, several local legal products substantially reflect Islamic teaching. The Deputy Secretary of Pengurus Cabang Nahdatul Ulama (PCNU) Sampang, Fahrur Rozi, explained that the enactment of positive legal regulations gives peace of mind and comfort while avoiding away any potential behaviors violating Islamic values. ${ }^{22}$

Fahrur Rozi further mentioned that the most important thing on a local regulation is its substance which leads to the process of building people's proseperity. He reasoned that ensuring civil rights

\footnotetext{
22 Interview with H. Fahrur Rozi, the vice chairman of PCNU Sampang in PCNU office, Juli 10, 2019.
} 
in people's daily lives is essential in Islamic legal system. Even, Imam Ghazali in his monumental book, Ihyâ' 'Ulûm al-dîn, emphasized that civil rights of citizenship are the main idea of Islamic sharia system which he popularly called it as maqashid al-shari'ah. This concept emphasizes that the main purposes of the enactment of Islamic law is to focus on: ${ }^{23}$

a. Hifdz al-nasl; the guarantee of human rights in the field of descendent lineage to not make it randomly mixed or confusing.

b. Hifdz al-nafs, the guarantee of human rights particularly the right to live a life and maintain souls which anyone should not take it away for any reasons.

c. Hifdz al-'aql, the guarantee of human rights in terms of freedom of thought and expressing the idea.

d. Hifdz al-dîn, the guarantee of human rights in terms of belief in religious values and freedom in performing all forms of religious rituals and traditions.

e. Hifdz Mâl, the guarantee of human rights in terms of property confirming that Islam is never aside to the concept of wealth.

Apart from discussion above, 1 (one) regional legal product in Sampang reflects Islamic nuance. It is the Sampang Regent Circular Letter No. 451 / 024.1 / 434.013 / 2019 concerning suggestion to pray congragetionally for all governmental officers and all Sub-District Heads in Sampang. In his introduction, the Regent affirmed that the existence of this letter aims to increase the belief to Allah among Sampang officers and Sub-District Heads.

In addition, Sampang has drafted a regional regulation on Madrasah Diniyah which is considered to be the most important part in maintaining Islamic values living in community's daily lives. The regulation also gives a significant effect especially in day-to-day activities for students to maintain the concept of living in harmony with Islamic values.

\footnotetext{
${ }^{23}$ Muwaffiq Jufri, “Nuansa Maqhasidu al-Syari'ah dalam Undang-undang No. 39 tahun 1999 tentang Hak Asasi Manusia", : e-journal.metrouniv.ac.id : http://ejournal.metrouniv.ac.id/index.php/istinbath/article/view/735 (Accessed on 21 March, 2019).
} 


\section{Sharia-Nuanced Regional Legal Products in Sumenep}

Just like in Sampang, it is also difficult to find any sharia-based legal products in Sumenep. According to Ananta Yuniarto, The Head of Legal Affairs of Sumenep Regional Representative Council (DPRD), the only sharia-based legal product in Sumenep regency is Perda No. 7 of 2002 concerning the Sharia Rural Bank (BPR) Sumekar.

Eventhough Sumenep does not have many sharia regulations; some local regulations indirectly reflect Islamic values. One of them is Perda No. 3 of 2002 concerning Public Order. This regulation contains a No. of regulatory nomenclature which are very accordance with Islamic values, such as prohibition of doing actions which potentially disturbs people's comfort, prohibition of illegal racing on the highway, prohibition on using alcoholic beverages, and other forms of regulations that relate to Islamic nuance.

In other words, these Perda are substantially in accordance with Islamic values. Perda No. 3 of 2002 has even absorbed beliefs, values, and provisions of Islamic law into regional regulation materials. Thus, labeling any local legal products under the name "sharia" seems to no longer needed because the most important thing is the substance and implementation instead of any attached sharia label.

\section{Sharia-Nuanced Regional Legal Products in Bangkalan}

Since long time ago, Bangkalan has been well known for its mastery on Islamic classical science. In the era of the 1800s, this district was once a reference for Islamic scholarship. Several famous ulama and the founders of Islamic boarding schools (pesantren) in Java are the alumni of Pesantren Kademangan led by a prominent scholar namely KH. Muhammad Kholil bin Abdul Latif or popularly called "Shaykhona Kholil" and "Mbah Kholil".

Relating to the shariah regional regulation in Bangkalan, its embryo had just arisen in the past 4 years. ${ }^{24}$ It is very interesting to find a fact that Bangkalan was planning a Regional Regulation on the Implementation of Sharia Tourism. However, the discussion on this took much time because of continual polemic between those who agree and those who disagree on the regulation. The dispute was

${ }^{24}$ Interview with KH. Makki Nashir, the chair of PCNU Bangkalan, conducted on July 7, 2019. 
especially on the existence of the term sharia which triggered debate on whether it applies for Muslims or the whole community.

Helmy Boymia, one of drafting experts of this regulation mentioned that the important thing in regional regulation on Sharia Tourism is to capture Islamic values and customs of Bangkalan then formulate them in general regulation which applies to all Bangkalan people. As a consequence, the word sharia, is eventually agreed to get removed. ${ }^{25}$

Another effort to absorb Islamis values in Bangkalan regional regulation is also clear from the plan to change the name of Bangkalan from the "City of Santri" to the "City of Dhikr and Shalawat." This came true when the Regional Government officially declared Bangkalan as the City of Zikr and Shalawat along with local leaders of pesantren and Islamic organizations on August 28, 2015. The declaration was then followed up by a plan of regional government and the representative council of Bangkalan (DPRD) to issue a Regional Regulation on the "City of Dzikir and Shalawat" as a commitment of the declaration. ${ }^{26}$ According to the Chairman of NU Bangkalan, K. Makki, the new name of Bangkalan is a reflection of Islamic values as the foundation in everyday life. ${ }^{27}$

Furthermore, DPRD Bangkalan explained that the change of name actually goes along with the change of era which is actually inevitable. In this globalization era in which human civilization moves continuously and influences human life, its enormous impact is clear especially on the development of cultural values including those in Bangkalan. Bangkalan people who used to uphold cultural values such as togetherness, family harmony and religious values are mentioned to begin to shift these noble values.

Some recent phenomenons, moreover, reflect moral degradation of Bangkalan people such as viral pornographic videos, a woman's half-nude photo taken in Paseban Park, even at the level of local

25 Interview with Mr. Helmi Boymia, a lecturer of Fakultas Hukum UTM Bangkalan, conducted on July 7, 2019.

26 Ant Jurnalis, "Bangkalan Dideklarasikan sebagai Kota Dzikir dan Shalawat", $\begin{array}{lccc}\text { news.okezone.com, } & 28 & \text { Agustus } & 2015 \\ \text { https://news.okezone.com/read/2015/08/28/519/1203923/bangkalan- }\end{array}$ dideklarasikan-sebagai-kota-zikir-dan-shalawat. (Accessed on 12 July, 2019).

27 Interview with KH. Makki Nashir, the chair of PCNU Bangkalan, conducted on July 7, 2019. 
government bureaucracy. It is reported that one of DPRD Bangkalan members committed obscene acts against his stepdaughter. Other cases also occured and this implies that modernism as a necessity in this era does not only lead to constructive changes but also deconstructs the existing social order. Into some extent, it even degrades social behavior of those who were once very pious and submissive to religious values.

On another hand, religious nuance in Bangkalan is still obvious. This could be seen in Bangkalan people daily lives which still get strongly attached to the culture of pesantren such as sarong and kopyah, reciting the Qur'an in langgar (Muslim small prayer room), and recitation of shalamat.

Therefore, the role of regional government is very important in realizing Bangkalan's goal as "The City of Dhikr and sholawat. This is particularly urgent to make the new name not merely as image building instrument or pseudo religious claim. Instead, it is supposed to show strong willingness and seriousness of both Bangkalan government and people to deal with nowadays challenges particularly in dealing with social and moral issues. Among others, turning the slogan into a living value system that really guides religious behavior in Bangkalan can be affirmed through Islamic local regulations while considerting the specific local wisdom of Bangkalan people.

In addition to the aforementioned plan, Bangkalan also plans a new Regional Regulation on Polygamy to be proposed in 2020. The urgency of regulating polygamy in local legal products aims as a preventive effort to avoid fornication among Bangkalan people. The existence of this initiative causes variety of responses particularly on the urgency of regulation. People are grouped into two, namely pro and contra responding this plan. ${ }^{28}$

\section{Conclusion}

Based on aforementioned explanations, the application and / or absorption of Islamic legal values in regional legal products in Madura have two types:

\footnotetext{
28 ina/pin, "Legislator Usulkan Pembentukan Perda Poligami", kabarmadura.id, 5 Agustus 2019 : https://kabarmadura.id/legislator-usulkan-pembentukan-perdapoligami/. (Accessed on July 7, 2019).
} 
First is direct absorption and/or application of regional legal products. This takes form in regional regulations or district regulations. In Pamekasan, there found several regional legal products including Regional Regulation No. 18 of 2001 concerning Prohibition of Alcoholic Beverages; Regional Regulation No. 18 of 2004 concerning Prohibition of Prostitution; Regional Regulation No. 7 of 2008 concerning Management of Zakat, Infaq and Sadaqah; Regional Regulation No. 5 of 2010 concerning Operational Costs for Hajj; Regional Regulation No. 4 of 2014 concerning Al-Qur'an Reading Skills for Muslim Students; Regional Regulation No. 5 of 2014 concerning Control of Activities in the Month of Ramadan; Regional Regulation No. 14 of 2014 concerning Hotel, Lodging and Boarding House Managements, and several other regional legal products.

Second is indirect absorption and/or application of the Islamic law values in regional legal products. Different from the previous, this substantially imports Islamic values in the legal products such as the Regulations No. 3 of 2002 concerning Public Order in Sumenep.

\section{Bibliography}

Abdul A'la., et al, "Islamism in Madura; From Religious Symbolism to Authoritarianism", Journal Of Indonesian Islam, Volume 12 No. 02, (December 2018).

Agung Ali Fahmi, "Suramadu Gratis, Awal Kebangkrutan Ekonomi Madura?". www.jawapos.com, 28 October 2018 : https://www.jawapos.com/jpgtoday /28/10/2018/suramadu-gratis-awal-kebangkrutanekonomi-madura. (Accessed on 21 March, 2019).

Agung Ali Fahmi, Implementasi Jaminan Hukum HAM Atas Kebebasan Beragama Di Indonesia. Yogyakarta : Interpena. 2011.

Agung Ali Fahmi, Implementasi Kebebasan Beragama Menurut UUD Republik Indonesia Tahun 1945. Jakarta. Tesis. Program Magister Hukum Kenegaraan. Fakultas Hukum. Universitas Indonesia. 2010.

Agung Ali Fahmi, Misbahul Munir, Yahya Suryawinata. Optimalisasi Fungsi Masjid Melalui Sertivikasi Wakaf Tanah Dan Penguatan Organisasi Takmir Sebagai Peningkatan Empati Sosial Serta Ekonomi Masyarakat Dalam Menangkal Radikalisme Agama Di 
Pamekasan. (Prosiding Seminar Nasional Budaya Madura I, Madura Dalam Kacamata Sosial, Budaya, Ekonomi, Agama, Kebahasaan dan Pertanian. Puslit Budaya dan Potensi Madura, LPPM UTM 2014).

Agung Ali Fahmi, Uswatun Hassanah and Yahya Suryawinata. "Resolusi Penolakan Daerah Terhadap Badan Pengelolaan Suramadu Pasca Jembatan Surabaya-Madura Dalam Perspektif NKRI". Seminar Nasional Industrialisasi Madura. Fakultas Teknik Universitas Trunojoyo Madura. 2015

Agung Ali Fahmi. "Peluang Hukum Propinsi Madura", Jawapos, 06 Oktober 2016

https://www.jawapos.com/opini/06/10/2016/peluanghukum-provinsi-madura. (Accessed on 21 March, 2019).

Ahmad Faisol, "Ulama Desak Legislatif Sahkan Bangkalan Dzikir dan Sholawat", surabaya.tribunnews.com, 24 Agustus 2015 : http://surabaya.tribunnews.com/2015/08/24/ulama-desaklegislatif-sahkan-perda-bangkalan-dzikir-dan-shalawat. (Accessed on 21 March, 2019).

Aniga, Sundari, and Erie Hariyanto. "Pengaruh Jenis Nasabah Dan Frekuensi Pencairan Pembiayaan Terhadap Profit Margin Di Bank Pembiayaan Rakyat Syariah (BPRS) Sarana Prima Mandiri Pamekasan." IQTISHADIA: Jurnal Ekonomi \& Perbankan Syariah, 2016. https://doi.org/10.19105/iqtishadia.v3i1.1054.

Ansori, dkk. Penyelesaian Konflik Aliran Keagamaan Berbasis Nilai Kearifan Lokal (Studi Kasus di Wilayah Madura), Fakultas Hukum Universitas Brawijaya dan berdasarkan Surat Perjanjian Nomor: 05/PKK-FHUB/PEN/2016.

Ant Jurnalis, "Bangkalan Dideklarasikan Sebagai Kota Dzikir dan Shalawat", news.okezone.com, 28 Agustus 2015 : https://news.okezone.com/read/2015/08/28/519/1203923/b angkalan-dideklarasikan-sebagai-kota-zikir-dan-shalawat. (Accessed on 12 July, 2019).

Eko/mas, "Susun Perda Dzikir dan Sjolawat, Ra Latif : Yang Penting Kita Bisa Mengaplikasikannya", www.bangkalankab.go.id, 28 November 2018 http://www.bangkalankab.go.id/v5/dat_berita.php?nart=13 49/Susun_Perda_Kota_Dzikir_dan_Sholawat,_Ra_Latif:_Yang 
Penting_Kita_Bisa_Mengaplikasikannya. (Accessed on 21 March, 2019).

Ghinan Salman, "Resmi Diratiskan, Jembatan Suramadu Jadi Non Tol", regional.kompas.com, 28 Oktober 2018 : https://regional.kompas.com/read/2018/10/28/07453791/re smi-digratiskan-jembatan-suramadu-jadi-jalan-non-tol. (Accessed on 21 March, 2019).

Hariyanto, Erie, and Mohammad Suyudi. "Jual Beli Benda Wakaf Untuk Pembangunan Masjid Istiqlal Di Desa Palengaan Daja Pamekasan." Al- Daulah: Jurnal Hukum Dan Perundangan Islam Daulah: Jurnal Hukum Dan Perundangan Islam 8, no. April (2018): 226-55. http://jurnalfsh.uinsby.ac.id/index.php/aldaulah/article/vie $\mathrm{w} / 665 / 531$.

Hariyanto, Erie, Muhammad Taufiq, Zainal Abidin, Miftahul Ulum, and Maimun. "Effectiveness of the Economic System to Zakat and Waqf for Empowerment of the Ummah in Indonesia." International Journal of Advanced Science and Technology 29, no. $06 \quad$ (2020): 1910-16. http:// sersc.org/journals/index.php/IJAST/article/view/128 $\underline{95}$.

Hariyanto, Erie. "Gerbang Salam: Telaah Atas Pelaksanaanya di Kabupaten Pamekasan," KARSA: Journal of Social and Islamic Culture 15, no. 1 (25 Maret 2012): 73-81.

Hariyanto, Erie. "Penyelesaian Sengketa Akad Pembiayaan Dalam Praktik Perbankan Syari'ah Di Kabupaten Pamekasan." Nuansa: Jurnal Penelitian Ilmu Sosial Dan Keagamaan Islam, 2013. https://doi.org/10.19105/nuansa.v10i2.172.

ina/pin, "Legislator Usulkan Pembentukan Perda Poligami", kabarmadura.id, $\quad 5 \quad$ August 2019 https://kabarmadura.id/legislator-usulkan-pembentukanperda-poligami/. (Accessed on 7 July, 2019).

JM. Muslimin, “Shari'a, Indigenous Wisdom and Human Rights (A Brief Review of Human Rights Enforcement in the Context of Indonesian History)", JOURNAL OF INDONESIAN ISLAM, Volume 09, No. 02, (2015). 
Maimun \& Ainul Haq, “Melacak Motivasi dan Efektivitas Peraturan Daerah Bernuansa Syariah di Pamekasan", Al-Ihkam, Volume 13, Nomor 2, (June 2018).

Makin, Al. "Unearthing Nusantara's Concept of Religious Pluralism: Harmonization and Syncretism in Hindu-Buddhist and Islamic Classical Texts." Al-Jami'ah: Journal of Islamic Studies 54, no. 1 (2016): 1. https://doi.org/10.14421/ajis.2016.541.1-30.

Makin, Al. “Unearthing Nusantara's Concept of Religious Pluralism: Harmonization and Syncretism in Hindu-Buddhist and Islamic Classical Texts." Al-Jami'ah: Journal of Islamic Studies 54, no. 1 (2016): 1. https://doi.org/10.14421/ajis.2016.541.1-30.

Mas, "Bupati-DPRD Kompak Pertahankan Perda Syariah", Globalnews, 24 Juli 2016 : http://globalnews.co.id/2016/06/bupati-dprd-kompak-pertahankanperda-syariah/. (Accessed on 21 March, 2019).

Mohammad Alim. "Perda Bernuansa Syariah dan Hubungannya Dengan Konstitusi", in Jurnal Hukum, Volume 17 Nomor 1, (2010).

Muchsin, Athik Yulia, Akhmad Farid Mawardi Sufyan, and Erie Hariyanto. “Urgensi Isbat Nikah Bagi Pasangan Yang Menikah Dibawah Umur Di Kabupaten Pamekasan." Al-Manhaj: Journal of Indonesian Islamic Family Law 1, no. 1 (October 14, 2019): 13-30.

Muchsin, Athik Yulia, Akhmad Farid Mawardi Sufyan, and Erie Hariyanto. “Urgensi Isbat Nikah Bagi Pasangan Yang Menikah Dibawah Umur Di Kabupaten Pamekasan." Al-Manhaj: Journal of Indonesian Islamic Family Law 1, no. 1 (October 14, 2019): 13-30.

Muwaffiq Jufri, "Nuansa Maqhasidu al-Syari'ah dalam Undangundang No. 39 tahun 1999 tentang Hak Asasi Manusia", : ejournal.metrouniv.ac.id:

http://ejournal.metrouniv.ac.id/index.php/istinbath/article/view/73 5 (Accessed on 21 March, 2019).

Muwaffiq Jufri, "Perbandingan Pengaturan Hak Kebebasan Beragama antara Indonesia dengan Majapahit", Jurnal Konstitusi, Nomor 2 Volume 14 (2017).

Supraptiningsih, Umi; Hariyanto Erie. "PERKAWINAN ANAK: Pandangan Ulama Dan Tokoh Masyarakat Pamekasan 
Agung Ali Fahmi, Muwaffiq Jufri, Ansori

Supraptiningsih | Jurnal Harkat: Media Komunikasi Gender." Jurnal Harkat: Media Komunikasi Gender, 2019. https://doi.org/10.15408/harkat.v15i2.13466.

Yanwar Pribadi, "Religious Networks in Madura (Pesantren, Nahdlatul Ulama and Kiai as the Core of Santri Culture)", AlJami'ah, Volume. 51, No. 1, (2013 M/1434 H). 